\title{
Saliva as a promising biofluid for SARS-CoV-2 detection during the early stages of infection
}

\author{
Briceida López-Martínez"\#, Ana L. Guzmán-Ortiz" ${ }^{2 \#, ~ A b r a h a m ~ J . ~ N e v a ́ r e z-R a m i ́ r e z ², ~ I s r a e l ~ P a r r a-O r t e g a ", ~}$ \\ Víctor B. Olivar-López ${ }^{3}$, Tania Ángeles-Floriano ${ }^{1,2}$, Armando Vilchis-Ordoñez¹, and Héctor Quezada ${ }^{2 \star}$ \\ ${ }^{1}$ Laboratorio Clínico; ' 2 Laboratorio de Investigación en Inmunología y Proteómica; ${ }^{3}$ Departamento de Urgencias. Hospital Infantil de México Federico \\ Gómez, Mexico City, Mexico. "These authors contributed equally to this work
}

\begin{abstract}
Background: Diagnostic testing for coronavirus disease (COVID)-19 is performed using nasopharyngeal swabs. This type of sampling is uncomfortable for the patient, dangerous for health workers, and its high demand has led to a global shortage of swabs. One of the alternative specimens is saliva. However, the optimal conditions for the test have not been established. Methods: Reverse transcription-polymerase chain reaction was used to detect the viral genome in saliva samples kept at room temperature, in the fridge or frozen for 2 days. In addition, the influence of brushing teeth and feeding on the detection of the virus in saliva was addressed. Finally, the efficiency of saliva in revealing the presence of the virus during the hospitalization period was determined in children. Results: The viral genome was consistently detected regardless of the storage conditions of saliva samples. Brushing teeth and feeding did not influence the sensitivity of the test. In hospitalized children, positive results were obtained only during the early days. Conclusions: These results support the idea of the use of saliva as an alternative specimen for diagnostic testing for COVID-19. The viral genome is stable and endures perturbations in the oral cavity. However, clearance of the virus from the mouth during the infection may limit the use of the test only to the early stages of the disease.
\end{abstract}

Key words: Saliva. Coronavirus disease-19. Children.

\section{La saliva como biofluido promisorio para la detección del SARS-CoV-2 durante las primeras etapas de la infección}

\section{Resumen}

Introducción: El diagnóstico de COVID-19 (enfermedad por coronavirus 2019) se realiza con un hisopado nasofaríngeo. El procedimiento de toma de muestra es molesto para el paciente y peligroso para el personal de salud, y la alta demanda de análisis ha conducido a la escasez de hisopos. Una alternativa es el uso de saliva, pero las condiciones óptimas para realizar el estudio no han sido establecidas. Métodos: Se usó la reacción en cadena de la polimerasa con transcriptasa reversa para detectar el genoma viral en muestras de saliva mantenidas a temperatura ambiente, en refrigeración o congeladas. Además, se evaluó la influencia del aseo bucal y de la ingesta de alimento en la detección del virus. Finalmente, se

Correspondence:

*Héctor Quezada

E-mail: hquezada@ @imfg.edu.mx
Date of reception: 01-07-2020

Date of acceptance: 03-07-2020

DOI: 10.24875/BMHIM.20000204
Available online: 09-09-2020

Bol Med Hosp Infant Mex. 2020;77(5):228-233

www.bmhim.com 1665-1146/@ 2020 Hospital Infantil de México Federico Gómez. Published by Permanyer. This is an open access article under the CC BY-NC-ND license (http://creativecommons.org/licenses/by-nc-nd/4.0/). 
determinó el desempeño de la saliva para reportar la presencia del virus durante el periodo de hospitalización en niños. Resultados: El genoma viral fue estable durante 2 días a las diferentes temperaturas ensayadas. El aseo bucal y la ingesta de alimento no influyeron en la detección del virus. En los niños hospitalizados solo se obtuvieron resultados positivos durante los primeros días. Conclusiones: Los resultados coinciden con la idea del uso de la saliva como biofluido alternativo para el diagnóstico de COVID-19. El genoma viral es estable y no se ve afectado por perturbaciones en la cavidad oral; sin embargo, la dinámica de la infección puede provocar que el ensayo solo sea útil durante las primeras etapas de la enfermedad.

Palabras clave: Saliva. COVID-19. Niños.

\section{Introduction}

After the shutdown period caused by the coronavirus disease (COVID-19) pandemic, economic activities are resuming while the number of new cases is still growing in some countries. Moreover, a future second wave of infections is a latent possibility as well. Diagnostic testing is crucial to suppress the spread of COVID-19 in people who have symptoms of respiratory illness, as well as in asymptomatic exposed subjects, and convalescent patients who may still be infectious. The current gold-standard test is reverse transcription-polymerase chain reaction (RT-PCR) using a nasopharyngeal swab (NPS) ${ }^{1}$. It detects parts of the severe acute respiratory syndrome coronavirus 2 (SARS-CoV-2) genome explicitly from a few hundreds of viral particles in a swab sample ${ }^{2,3}$. However, NPS must be obtained by a trained health worker; also, it is uncomfortable for the patient who may bleed, sneeze or cough, posing a high risk of virus transmission to the person who is taking the sample and is affected by the global shortage of swabs. In addition, children may be uncooperative, increasing the risk of nasal trauma'.

Saliva is an attractive alternative specimen because the patient can collect it in a non-invasive way, and the results from saliva samples complied with those from NPS in $31-100 \%$ of samples obtained from positive patients ${ }^{4-13}$. The SARS-CoV-2 particles in saliva can result from the migration of infected cells to the lower and upper respiratory tract ${ }^{14}$ or from infection in the oral cavity, especially the tongue ${ }^{15}$.

Diagnostic testing of NPS is a well-established procedure $^{1-3}$. However, little is known about the optimal condition to test saliva. Collection of specimens has been obtained by passive drooling (100\% match between NPS/saliva) ${ }^{8}$, spitting the first saliva in the morning $(92 \% \text { match })^{7}$, coughing up saliva from the throat before spit $(85-92 \% \text { match })^{4,5,9,11}$, with the use of buccal swabs $(82 \% \text { match })^{13}$, and directly from the salivary gland canal $(31 \% \text { match })^{10}$. Passive drooling may be more suitable for children because not all of them can easily cough up, and buccal swabs may be convenient in infants who are too young to spit.
The high analytical sensitivity of the RT-PCR test may be hampered in the clinic due to time-dependent changes in nasopharynx and mouth viral load. For example, in patients incubating the virus, those in which viral shedding is migrating from upper to lower respiratory tract, or individuals recovering from the infection ${ }^{14}$.

Knowledge about the sensitivity of diagnostic testing in saliva along the course of infection may be useful to adopt this biofluid as an alternative specimen and to address the potential of virus transmission by infected persons. In the present study, changes in the capacity of saliva to report the presence of the SARS-CoV-2 virus were evaluated as a function of storage conditions of the sample, conditions of the mouth, and evolution of infection.

\section{Methods}

\section{Participants and sample collection}

All participants were positive in an NPS RT-PCR assay. Saliva specimens from two hospitalized children and two adolescents at the Hospital Infantil de Mexico Federico Gómez were collected. Participants were asked to gently spit approximately $2 \mathrm{ml}$ of saliva in sterile $50 \mathrm{ml}$ centrifuge plastic tubes. From the two adolescent participants, a unique saliva sample was collected in their first day of hospitalization and aliquots were kept at $4^{\circ} \mathrm{C},-30^{\circ} \mathrm{C}$ or at room temperature up to $48 \mathrm{~h}$. Two children provided several samples during their hospitalization. After collection, closed tubes were kept in a hard plastic box at room temperature until RNA was extracted (no more than $4 \mathrm{~h}$ ). One adult recovering at home provided two samples per day: one of the first salivae in the morning and the other after brushing teeth, having breakfast, and brushing teeth again for 4 consecutive days. In this case, closed tubes were placed into a plastic bag with a hermetic seal, which in turn was placed into a closed hard plastic box and kept in the fridge. On completion of the sampling, the closed box was transported to the laboratory. 
Table 1. Clinical characteristics of participants

\begin{tabular}{|l|l|c|l|l|}
\hline $\begin{array}{l}\text { Age } \\
\text { (years) }\end{array}$ & Gender & $\begin{array}{c}\text { Days after onset of } \\
\text { respiratory } \\
\text { symptoms* }\end{array}$ & Other morbidities & Experiment \\
\hline 16 & Male & 5 & $\begin{array}{l}\text { Recovering from renal } \\
\text { transplant }\end{array}$ & Stability at different temperatures (Fig. 1) \\
\hline 15 & Male & 4 & Acute lymphoblastic leukemia & Stability at different temperatures (Fig. 1) \\
\hline 4 & Male & 4 & Hepatoblastoma & Saliva sampling along hospitalization (Table 2) \\
\hline 4 & Female & 5 & Hydronephrosis & Saliva sampling along hospitalization (Table 2) \\
\hline 56 & Male & 3 & None & Before and after tooth brushing and breakfast (Fig. 2) \\
\hline
\end{tabular}

${ }^{*}$ Before the first sample was taken.

\section{Virus detection}

Viral RNA was extracted with the spin column-based Kit RNAv-090 from BioPure. For RT and amplification of the viral genes, the GeneFinder COVID-19 PLUS RealAmp Kit (MFK-45, GeneFinder) was used. If Ct (cycle threshold) was $<40$ for at least one viral gene, the result was positive. If only one viral gene was amplified with $\mathrm{Ct}$ $>40$, the result was undetermined. If the internal control showed a clear amplification and any viral gene showed a signal, the result was negative.

\section{Results}

The clinical characteristics of participants are shown in table 1.

\section{Storage of saliva samples at room temperature, $4^{\circ} \mathrm{C}$ or $-30^{\circ} \mathrm{C}$ preserves the viral genome for 2 days}

Aliquots of samples from two participants were analyzed the day of collection and after storage, for 1 and 2 days at room temperature, in the fridge, or the freezer to test the stability of the viral genome in saliva during $48 \mathrm{~h}$ after collection. Positive results were consistently obtained in all samples without changes in the Ct values of viral genes (Fig. 1).

\section{The SARS-CoV-2 virus can be detected in saliva a few minutes after brushing teeth and feeding}

One of the aspects to consider when using saliva as a specimen is if the first salivae in the morning are better than those collected at any hour of the day and if perturbations in the oral cavity affect the sensitivity of the assay. Therefore, the presence of the virus was compared between samples of the first saliva in the morning, and approximately 15 min after having breakfast and brushing teeth for 4 consecutive days by an adult participant recovering at home. Paired samples were available only for days 1,2 , and 4 , in which the viral genome was detected in both conditions with similar $\mathrm{Ct}$ values (Fig. 2A). On day 3, the sample of the first saliva in the morning was negative and not enough for analysis after having breakfast and tooth brushing.

\section{The SARS-CoV-2 virus was not consistently detected in the saliva of two children during their hospitalization}

Saliva may be a good specimen to report the presence of the virus during the early stages of infection, and optimally, it should work during the disease progression and should become negative when the patient is not infected anymore. Therefore, samples from two children were analyzed during their hospitalization periods (5 and 12 days, respectively). In the first case, the test resulted positive only on day one (Table 2). In the second case, three out of six samples resulted positive on days 1, 2, and 6 (Table 2).

The use of spin columns kits for viral RNA extraction from saliva is a feasible option for the SARS-CoV-2 detection assay

The high viscosity of some saliva samples prevents accurate pipetting, and its high protein content may clog to some extent the silica resin of spin columns during the extraction procedure. Despite this, using raw saliva without any transport media or additive, we could detect the presence of the viral genome. Overall, we analyzed samples from five different participants. As diagnosis was initially confirmed with a positive result from an NPS, we 


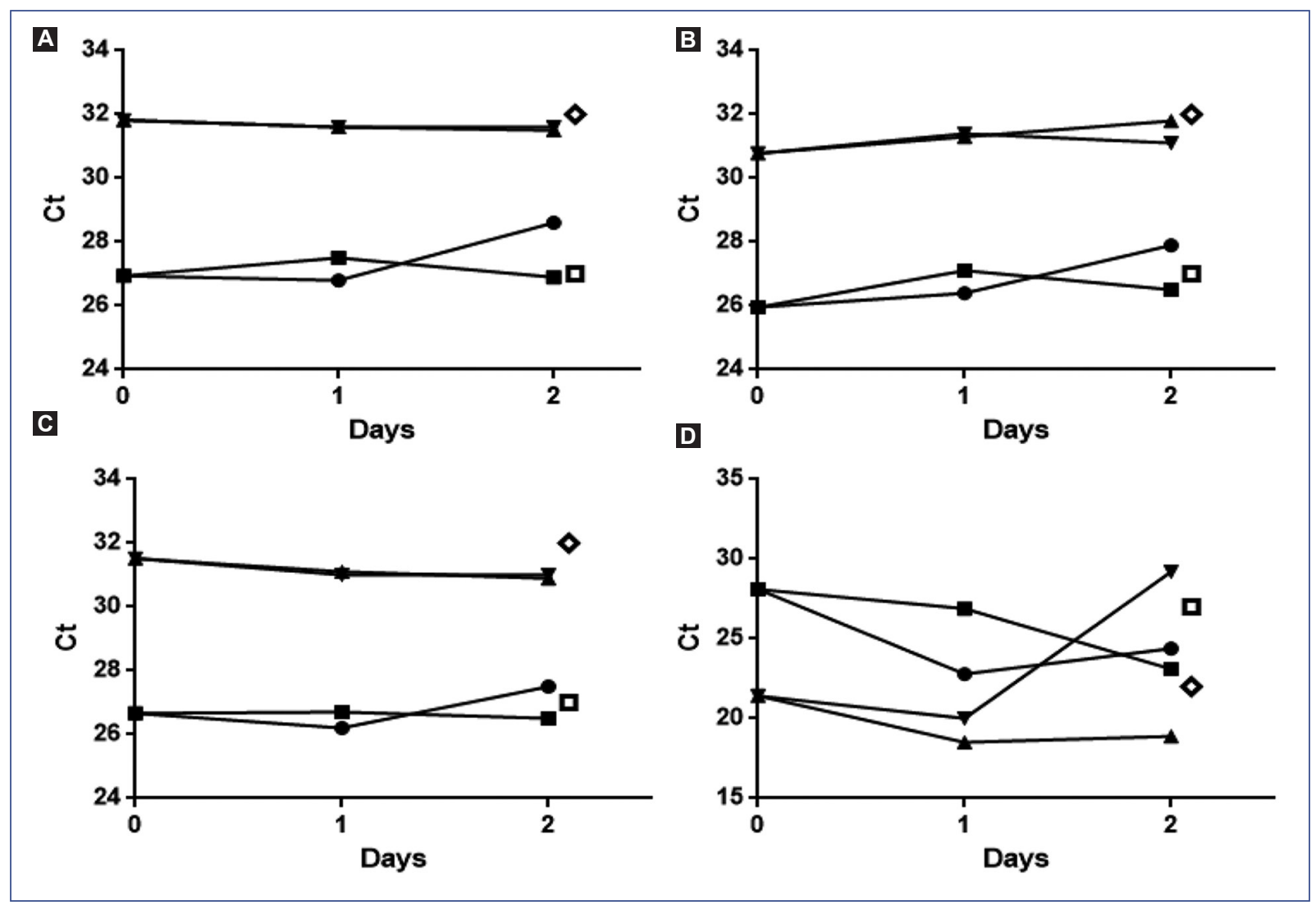

Figure 1. Saliva preserves the viral genome. The saliva of two participants was aliquoted and kept at different temperatures before RT-PCR analysis. The corresponding Ct values were plotted as a function of time. Participant 1: $\bigcirc$, room temperature; $\mathbf{\square}, 4^{\circ} \mathrm{C}$; and $\square,-30^{\circ} \mathrm{C}$. Participant 2: $\boldsymbol{\Delta}$, room temperature; $\boldsymbol{\nabla}, 4^{\circ} \mathrm{C}$; and $\diamond,-30^{\circ} \mathrm{C}$. The amplified viral genes were (A) Orf-1ab, (B) S, and (C) N; (D) hRP as an internal control. RT-PCR: reverse transcription-polymerase chain reaction; Ct: cycle threshold; hRP: human RNAse P.

Table 2. Time course of SARS-CoV-2 detection in the saliva of two hospitalized children

\begin{tabular}{|l|c|c|c|c|c|c|c|c|c|c|c|c|c|}
\hline & \multicolumn{10}{|c|}{ Days of hospitalization } \\
\cline { 2 - 28 } & $\mathbf{1}$ & $\mathbf{2}$ & $\mathbf{3}$ & $\mathbf{4}$ & $\mathbf{5}$ & $\mathbf{6}$ & $\mathbf{7}$ & $\mathbf{8}$ & $\mathbf{9}$ & $\mathbf{1 0}$ & $\mathbf{1 1}$ & $\mathbf{1 2}$ & $\mathbf{1 3}$ \\
\hline Patient 1 & + & U & - & - & - & NT & NT & NT & NT & NT & NT & NT & NT \\
\hline Patient 2 & + & + & NT & NT & - & + & NT & NT & NT & U & NT & NT & - \\
\hline
\end{tabular}

U: undetermined result; SARS-CoV-2: severe acute respiratory syndrome coronavirus 2; NT: not tested.

obtained a $100 \%$ agreement between the first saliva sample taken from each participant and the NPS test. This result is similar to those reported in other studies using spin columns ${ }^{8}$ or magnetic particles-based automated technology for viral RNA isolation ${ }^{4-7,9,11,13}$ (Table 3).

\section{Discussion}

Although saliva is an attractive option as a specimen for SARS-CoV-2 detection, several methodological issues must be systematically explored before it can be used in the clinic.

At present, the presence of the virus is addressed by the detection of its genome, although it does not necessarily mean the presence of active infective viral particles $^{16}$. However, the stability of viral particles is desirable for diagnostic testing because it relaxes the conditions of storage and transport to the laboratory. Our results demonstrated that, for samples with $\mathrm{Ct}$ values within the range of positive results (26-32), the viral 
Table 3. Comparison of SARS-CoV-2 detection in NPS and saliva.

\begin{tabular}{|l|l|l|l|l|}
\hline $\begin{array}{l}\text { Match between } \\
\text { saliva/NPS results }\end{array}$ & Sample collection & $\begin{array}{l}\text { Viral RNA extraction } \\
\text { procedure }\end{array}$ & Age group & Reference \\
\hline $85 \%(49 / 58)$ & Cough up the first saliva in the morning. Posterior oropharyngeal & Magnetic particles & Adults \\
\hline $88 \%(37 / 42)$ & Deep cough 3-5 times before spitting & Magnetic particles & Adults \\
\hline $85 \%(33 / 39)$ & Spit gently. Use of transport media 1:1 & Magnetic particles & Adults \\
\hline $92 \%(35 / 38)$ & Spit the first saliva in the morning & Magnetic particles & Adults \\
\hline $100 \%(25 / 25)$ & Passive drooling & Spin column kit & Adults \\
\hline $87 \%(20 / 23)$ & First saliva in the morning. Posterior oropharyngeal & Magnetic particles & Adults \\
\hline $31 \%(4 / 13)$ & Cotton swabs from salivary gland canal & - & Adults \\
\hline $92 \%(11 / 12)$ & Cough out saliva from throat & Magnetic particles & Adults \\
\hline $73 \%(8 / 11)$ & - & - & Children \\
\hline $82 \%(9 / 11)$ & Buccal swabs on the buccal mucosa (bilateral) & Magnetic particles & Children \\
\hline
\end{tabular}

genome is stable for 2 days if kept at room temperature, in the refrigerator, or after a freeze-thaw cycle. These conditions cover the most common types of storage and transport of clinical samples. The RNase activity of saliva ${ }^{17}$ does not reach the viral genome, suggesting the presence of intact viral particles at the different tested temperatures.

Regarding conditions of the oral cavity, our results indicate that the first saliva in the morning is as good as that obtained $\approx 15$ min after breakfast and brushing teeth for the detection of the virus. This result supports the notion that saliva is a robust biofluid for COVID-19 diagnosis. Regardless, these results must be confirmed with more participants. It is important to note that one out of the seven samples shown in figure 2 was negative (first saliva in the morning at day 3 ), indicating that even during the early days of infection, the saliva test is not $100 \%$ reliable.

In two reports of SARS-CoV-2 detection in the saliva of children ${ }^{12,13}$, the virus becomes undetectable in saliva by days 8-10 after the onset of symptoms, while it was still detectable in NPS. Han et al. reported a steeper decline of viral load in saliva compared to $\mathrm{NPS}^{12}$. Accordingly, one of the two children showed a very fast negativization. The other had a prolonged hospitalization, but positive results were consistently obtained only during the first two determinations (Table 2). These results are consistent with the idea that saliva may be a good option for COVID-19 diagnosis only during the early stages of infection. Further studies are necessary to determine the time-dependent changes of viral clearance in the mouth of children.

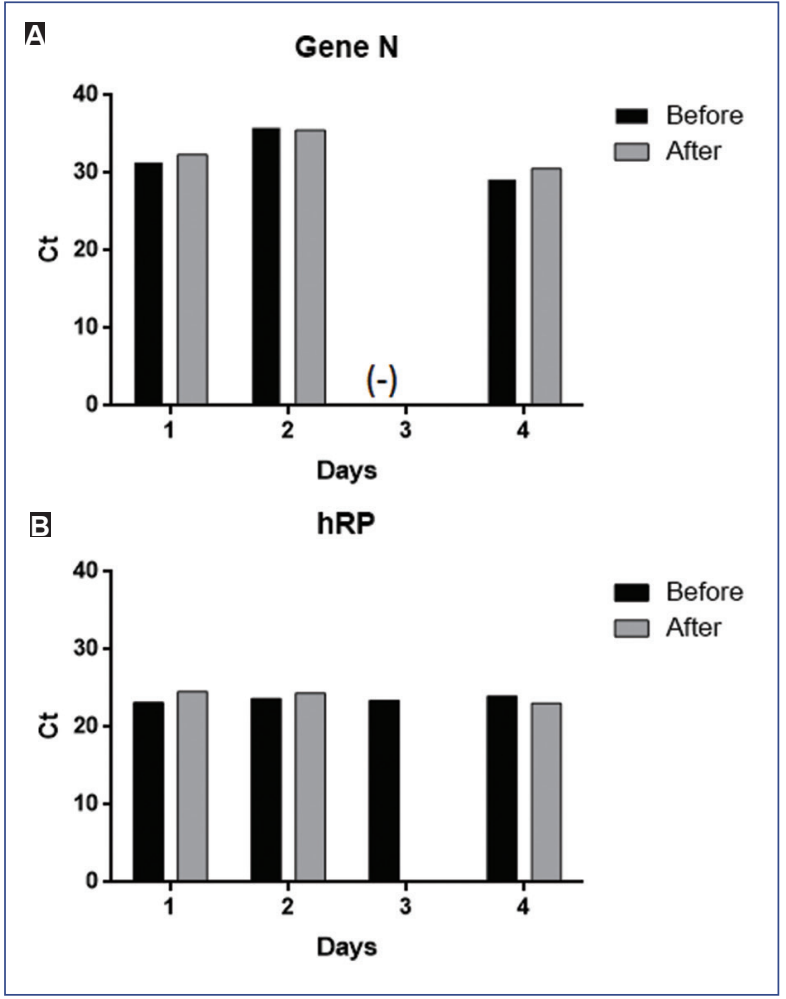

Figure 2. Detection of the viral genome in the saliva is not affected by brushing teeth and feeding. (A) The viral gene $\mathrm{N}$ or (B) the internal control RNAse $P$ from human samples were RT-PCR amplified using the first saliva in the morning before (black bars) or after oral hygiene and having breakfast (grey bars) for four consecutive days. On day three, the first saliva in the morning was negative, and not enough sample was collected for analysis after oral hygiene and breakfast. 
At present, most of the reported comparisons between NPS and saliva use magnetic particles-based automated technology to extract viral RNA (Table 3). However, not all laboratories have such instrumentation. The use of spin-column kits only needs a microfuge and, unquestionably, a biosafety level two laboratory setting. Although a high number of paired samples is required to compare the sensitivity of two extraction methods, our results indicate that the simple benchtop extraction method is sensitive enough to reveal the presence of the viral genome.

\section{Ethical disclosures}

Protection of human and animal subjects. The authors declare that no experiments were performed on humans or animals for this study.

Confidentiality of data. The authors declare that they have followed the protocols of their work center on the publication of patient data.

Right to privacy and informed consent. The authors have obtained the written informed consent of the patients or subjects mentioned in the article. The corresponding author has this document.

\section{Conflicts of interest}

The authors declare no conflicts of interest.

\section{Funding}

CONACYT (Consejo Nacional de Ciencia y Tecnología), project number: 312386.

\section{References}

1. Fang FC, Naccache SN, Greninger AL. The laboratory diagnosis of COVID-19-frequently-asked questions. Clin Infect Dis. 2020;2020:ciaa742.

2. Zhen W, Manji R, Smith E, Berry GJ. Comparison of four molecular in vitro diagnostic assays for the detection of SARS-CoV-2 in nasopharyngeal specimens. J Clin Microbiol. 2020;58:e00743-20.

3. Lieberman JA, Pepper G, Naccache SN, Huang ML, Jerome KR, Greninger AL. Comparison of commercially available and laboratory-developed assays for in vitro detection of SARS-CoV-2 in clinical laboratories. J Clin Microbiol. 2020;58:e00821-20.

4. Chen JH, Yip CC, Poon RW, Chan KH, Cheng VC, Hung IF, et al. Evaluating the use of posterior oropharyngeal saliva in a point-of-care assay for the detection of SARS-CoV-2. Emerg Microbes Infect. 2020;9:1356-9.

5. Zheng S, Yu F, Fan J, Zou Q, Xie, G, Yang X, et al. Saliva as a diagnostic specimen for SARS-CoV-2 by a PCR-based assay: a diagnostic validity study. SSRN Electron J. 2020. [Preprint]. Available from: https:// papers.ssrn.com/sol3/papers.cfm?abstract_id=3543605.

6. Williams E, Bond K, Zhang B, Putland M, Williamson DA. Saliva as a non-invasive specimen for the detection of SARS-CoV-2. J Clin Microbiol. 2020;58:e00776-20.

7. Wyllie AL, Fournier J, Casanovas-Massana A, Campbell M, Tokuyama M, Vijayakumar $\mathrm{P}$, et al. Saliva is more sensitive for SARS-CoV-2 detection in COVID-19 patients than nasopharyngeal swabs. medRxiv. 2020. [Preprint]. Available from: https://doi.org/10.1101/2020.04.16.20067835.

8. Azzi L, Carcano G, Gianfagna F, Grossi P, Gasperina DD, Genoni A, et al. Saliva is a reliable tool to detect SARS-CoV-2. J Infect. 2020;81:e45ヌ50.

9. To KK, Tsang OT, Leung WS, Tam AR, Wu TC, Lung DC, et al. Temporal profiles of viral load in posterior oropharyngeal saliva samples and serum antibody responses during infection by SARS-CoV-2: an observational cohort study. Lancet Infect Dis. 2020;20:565囚74.

10. Chen L, Zhao J, Peng J, Li X, Deng X, Geng Z, et al. Detection of 2019$\mathrm{nCoV}$ in saliva and characterization of oral symptoms in COVID-19 patients. Lancet Infect Dis. 2020;12:11.

11. To KK, Tsang OT, Yip C, Chan KH, Wu TC, Chan JM, et al. Consistent detection of 2019 novel coronavirus in saliva. Clin Infect Dis. 2020;71:841-3.

12. Han MS, Seong MW, Kim N, Shin S, Cho SI, Park H, et al. Viral RNA load in mildly symptomatic and asymptomatic children with COVID-19, Seoul. Emerg Infect Dis. 2020;26:202449.

13. Kam KQ, Yung CF, Maiwald M, Chong CY, Soong HY, Loo LH, et al. Clinical utility of buccal swabs for SARS-COV-2 detection in COVID-19-infected children. J Pediatr Infect Dis Soc. 2020;9:370-2.

14. Hou YJ, Okuda K, Edwards CE, Martinez DR, Asakura T, Dinnon KH, et al. SARS-CoV-2 reverse genetics reveal a variable infection gradient in the respiratory tract. Cell. 2020;182:429-446.

15. Xu H, Zhong L, Deng J, Peng J, Dan H, Zeng X, et al. High expression of ACE2 receptor of 2019-nCoV on the epithelial cells of oral mucosa. Int J Oral Sci. 2020;12:8.

16. Wölfel R, Corman VM, Guggemos W, Seilmaier M, Zange S, Müller MA, et al. Virological assessment of hospitalized patients with COVID-2019. Nature. 2020;581:465区9.

17. Bardoń A, Shugar D. Properties of purified salivary ribonuclease, and salivary ribonuclease levels in children with cystic fibrosis and in heterozygous carriers. Clin Chim Acta. 1980;101:17区24. 